\title{
BACTERICIDAL AND FUNGICIDAL ACTIVITY OF THE WILD THYME (Thymus serpyllum) ESSENTIAL OIL
}

Department of Immunology, Microbiology and Physiological Chemistry, West Pomeranian University of Technology, Szczecin, Poland

\begin{abstract}
The aim of this study was to in vitro determine the antimicrobial activity of essential oil obtained from wild thyme (Thymus serpyllum) against three test microorganisms representing species: Escherichia coli, Staphylococcus aureus and Candida albicans. The research was carried out using the disk diffusion assay. The activity of TSL oil was analyzed at various concentrations ranging from $200 \mu \mathrm{L} / \mathrm{mL}$ to $2.0 \mu \mathrm{L} / \mathrm{mL}$, assessing the diameters of zones of inhibited growth. After averaging the obtained values, the range of antimicrobial activity of TSL was determined based on reference data. TSL essential oil showed only moderate inhibitory activity against $S$. aureus and $E$. coli at concentrations of 200 and $125 \mu \mathrm{L} / \mathrm{mL}$, and a large inhibitory effect against $C$. albicans at concentrations of 200,125 and $62.5 \mu \mathrm{L} / \mathrm{mL}$ and moderate at a concentration of $31.2 \mu \mathrm{L} / \mathrm{mL}$. On this basis, the MIC value was determined for the $C$. albicans test strain of $62.5 \mu \mathrm{L} / \mathrm{mL}$, considering it the most effective. In addition, it was found that carvacrol - one of the major components of TSL - can show strong growth inhibitory effects in both fungi and bacteria selected species.
\end{abstract}

Key words: antimicrobial activity, essential oil, wild thyme, Thymus serpyllum.

\section{INTRODUCTION}

Novadays, progress and new technologies are extremely important parts of animal and human lifes. Over the last fifty years, we can observe a rapid improvement in the field of aseptics in general, as well as care for a good, physiological state of the human bodies and livestock. There are many medicines and chemotherapeutics to combat fungal and bacterial infections, but chemical products tend to be less popular in a new trend of natural-origin substances. In the animal production, there is also one emerging problem corresponding with this trend - presence of antibiotic-resistant bacteria, due to misuse of antibiotics and other drugs in the animal industry, which is now contrary to good breeding and veterinary practice. Increase in the presence of antibiotic- and multidrug-resistant bacteria is important for the protection of human and animal health, because diseases caused by this type of bacteria do not respond to treatment, last longer and pose a much higher risk of death and economic loses. Antibiotic-resistant bacteria can also be transmitted by animals to humans - either in the food chain or during direct contact (Buczek and Marć 2009). The main sources of their

Corresponding author: Xymena Stachurska, Department of Immunology, Microbiology and Physiological Chemistry, West Pomeranian University of Technology, Szczecin, Piastów 45, 70-311 Szczecin, Poland, e-mail: xymena.stachurska@zut.edu.pl, ORCID: 0000-0002-1797-7550 
origin are municipal and hospital sewage, wastewater from animal husbandry, veterinary facilities and pharmaceutical plants (Łebkowska 2009). In this context, there is a dire need of looking for alternative bactericidal substances.

For the above-mentioned reasons, essential oils are very promising natural products with both bactericidal and fungicidal activity, which can be used in many branches of protection and care for livestock health. Certainly, it will also be quickly adopted and adapted by a part of the society thirsty for solutions that are least artificially processed or received. In general, essential oil (EO) is a liquid, volatile substance derived from plants, in terms of composition being a mixture of various chemical compounds, such as: ketones, aldehydes, alcohols, esters, lactones, terpenes and other organic compounds. EOs can occur in whole plants or in their parts and are most often found in special secretory tissue cells, in which they accumulate as the final metabolic product (Orzeszko-Rywka et al. 2010). Particularly noteworthy are oils extracted from plants belonging to the family Lamiaceae, ecpecially those representing the genus of Origanum and Thymus, the EOs of which are known to exhibit antimicrobial activity against bacteria, whom they owe largely their main chemical components: thymol and its isomer carvacrol (Skandamis et al. 2001). These compounds are classified as bioactive organic chemical compounds - phenols. Biological activity of the oils depends on their chemical composition that is determined by genotypic and environmental factors related to the plants, from which the EOs are extracted later (Burt 2004). Thymol and carvacrol, as components of EOs, have no adverse effect on human health and have been proved that they do not cause significant or even marginal toxic effects at the cellular level.

In addition, the concentrations, at which they exhibit antibacterial properties, are much lower than those that can lead to genotoxic changes (Stamatti et al. 1999; Burt 2004). In vitro studies conducted with compounds isolated from various EOs have shown, that they have a bactericidal or bacteriostatic effect. These compounds are lipophilic substances, and therefore, easily penetrate through the wall and cytoplasmic membrane of microorganisms causing disruption of their integrity. The mechanism of oils toxicity against bacteria consists in: coagulation of the cytoplasm and destabilization of the cytoplasmic membrane, which causes excessive loss of ions, which reduces membrane potential and interferes with the functioning of transmembrane pumps. The result is a reduction in intracellular ATP. Damage to the wall and cytoplasmic membrane ultimately leads to lysis of a bacterial cell. This effect was observed especially in the case of Gram-positive bacteria, to a lesser extent Gram-negative, which is probably associated with differences in the structure of their cell wall (Król et al. 2015). Thymus serpyllum, known as wild thyme, in terms of chemical composition contains $0.2-0.6 \%$ essential oil, about $5 \%$ tannins, bitterness compounds, organic acids, flavonoids, mineral salts and other compounds (Trąba et al. 2012).

Preparations from thyme increase secretory activity of the mucous membranes of the upper respiratory tract, increase the volume of residual mucus, that becomes more fluid. They also stimulate natural movements of the ciliary epithelium, which makes it easier to cough up. Tannins of thyme herbs inhibit the growth of intestinal microbes, and phenolic compounds of the oil have similar effect, but in the respiratory tract. Infusions of thyme externally applied to the skin are bactericidal and anti-inflammatory (Ożarowski and 
Jaroniewski 1987). Infusions of thyme used orally have an activity primarly as an expectorant, diastolic and disinfectant in catarrh of the mouth, throat, larynx and bronchi, combined with residual mucus secretions, tiring, persistent dry cough, and also in infection with pyogenic bacteria (Trąba et al. 2012).

The aim of this work was to determine the in vitro antimicrobial activity of essential oil obtained from Thymus serpyllum against three types of microorganism strains representing following species: Escherichia coli, Staphylococcus aureus and Candida albicans.

\section{MATERIAL AND METHODS}

The reference strains used for this study came from ATCC (American Type Culture Collection) and represented respectively: Gram-positive cocci (Staphylococcus aureus ATCC ${ }^{\circledR} 25923^{\mathrm{TM}}$ ), Gram-negative rods (Escherichia coli ATCC ${ }^{\circledR} 11775^{\mathrm{TM}}$ ) and yeast (Candida albicans $A T C C^{\circledR} 10231^{\mathrm{TM}}$ ). Strains were stored at $-20^{\circ} \mathrm{C}$ in TSB (Oxoid) with $10 \%$ glycerol until the analyses. The name of the used essential oil (TSL) derives from the Latin name Thymus serpyllum $\mathrm{L}$. The oil was obtained by hydro-distillation of the above-ground parts of thyme, and then examined by gas chromatography GC-MS (Gas Chromatography-Mass Spectrometry) in terms of chemical composition. Forty-seven compounds $(99.67 \%$ of the total oil) were identified, of which the main components were: carvacrol (37.49\%), terpinene (10.79\%), $\beta$-caryophyllene (6.51\%), p-Cymene (6.06\%), (E)- $\beta$-ocymen (4.63\%) and $\beta$-bisabolen (4.51\%) (Wesołowska et al. 2015). Previous research also showed that factors such as distillation time and type of apparatus used for distillation had no effect on the content of essential oil, and had no significant effect on the content of the main components of the oil (Wesołowska et al. 2012, 2014). TSL essential oil has been made available for this research courtesy of Aneta Wesołowska from the Institute of Chemistry and Fundamentals of Environmental Protection, Department of Organic Chemistry, ZUT in Szczecin.

The research methodology has been developed based on data contained in Lević et al. (2011) with own modification. Three reference test strains (S. aureus ATCC ${ }^{\circledR} 25923^{\mathrm{TM}}$, E. coli ATCC $^{\circledR} 11775^{\mathrm{TM}}$ and C. albicans $A T C C^{\circledR} 10231^{\mathrm{TM}}$ ) were revived from the frozen state by incubation at room temperature for 30 minutes. Strains were then streaked on BHI Agar (Brain Heart Infusion Agar, Oxoid) and incubated at $37^{\circ} \mathrm{C}$ for $18-24$ hours in a Galaxy S + incubator (RS Biotech). Then, in order to prepare a suspension from the obtained cultures with a turbidity of 0.5 of the McFarland standard (inoculum of approx. $1.5 \times 10^{8} \mathrm{CFU} / \mathrm{mL}$ for S. aureus and $E$. coli and $1-5 \times 10^{6} \mathrm{CFU} / \mathrm{mL}$ for $C$. albicans), several colonies were picked and resuspended in $0.85 \%$ saline. The suspensions were mixed by vortexing and then their optical density was determined using a densitometer (DEN-1, Biosan). Suspensions prepared from $S$. aureus and $E$. coli were plated on BHI agar using bacterial lawn assay method and in case of $C$. albicans on Sabouraud Dextrose Agar (Oxoid). For streaking, $0.1 \mathrm{~mL}$ of the suspension was withdrawn using an Eppendorf automatic pipette and then transferred onto the surface of plates with an appropriate nutrient medium. The test microbial suspensions were spread over the entire surface of the substrate using sterile cell spreader. Test strains prepared this way were used to determine the antimicrobial activity of the analyzed TSL essential oil. 
The antimicrobial activity of TSL oil was determined by the disk diffusion assay (Kirby-Bauer method). This is a qualitative method based on the diffusion of substance contained in the disc into the solid substrate. The antibacterial substance diffuses radially, creating zones with a concentration gradient. The size of the growth inhibition zone of the microorganism is directly proportional to the degree of its sensitivity to the substance - the greater the zone of inhibition, the more sensitive the microorganism. Depending on the size of the zone and adopted assessment criteria, microorganisms are defined as: sensitive and resistant or sensitive, medium sensitive and resistant (Borowska et al. 2014). For the TSL essential oil, a series of dilutions were made yielding respectively: $200 \mu \mathrm{L} / \mathrm{mL}, 125 \mu \mathrm{L} / \mathrm{mL}, 62.5 \mu \mathrm{L} / \mathrm{mL}$, $31.2 \mu \mathrm{L} / \mathrm{mL}, 15.6 \mu \mathrm{L} / \mathrm{mL}, 7.8 \mu \mathrm{L} / \mathrm{mL}, 3.9 \mu \mathrm{L} / \mathrm{mL}, 2.0 \mu \mathrm{L} / \mathrm{mL}$. Dilutions were prepared in propylene glycol (Chempur) in $0.5 \mathrm{~mL}$ Eppendorf tubes. At the same time, paper discs with a diameter of $5 \mathrm{~mm}$ were prepared, which were sterilized in an autoclave and then placed under the laminar chamber. Then $10 \mu \mathrm{l}$ of TSL essential oil was taken from the appropriate dilution and soaked into paper discs. In addition, to assess the toxicity of carvacrol, three discs soaked in $10 \mu \mathrm{L}$ of $100 \%$ carvacrol (Sigma-Aldrich Co. LLC.) solution were prepared one for each test strain. Negative control was also prepared as discs soaked in $10 \mu \mathrm{L}$ of $100 \%$ propylene glycol. The discs with subsequent dilutions of the TSL essential oil dried completely under the laminar chamber and then were applied onto the surface of the bacterial lawns, as shown in Fig. 1.

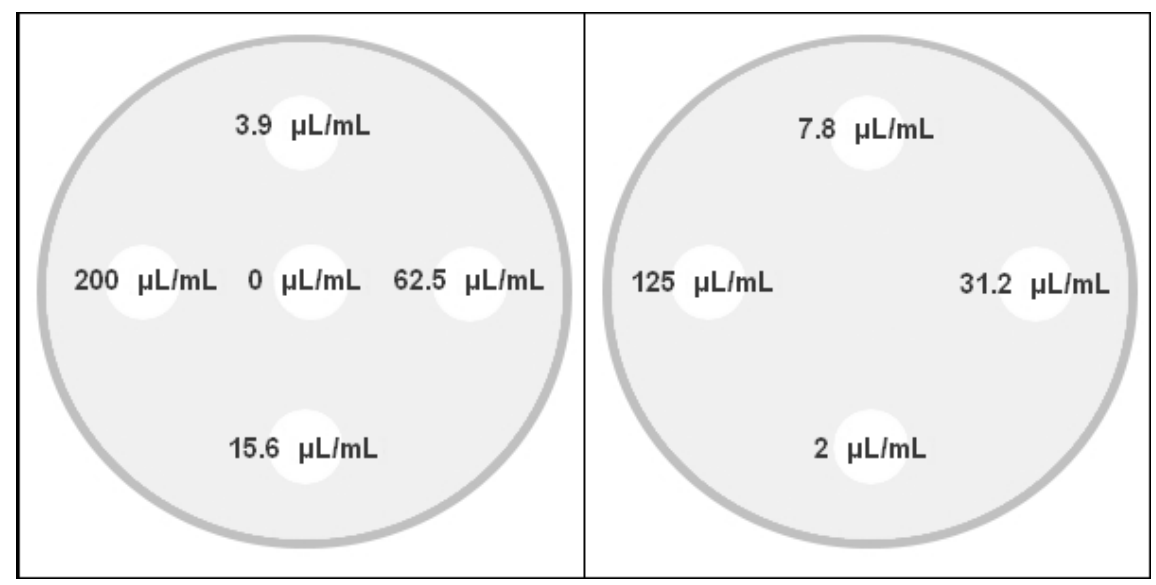

Fig. 1. Arrangement of paper discs, saturated with a solution of TSL essential oil of various concentrations, on the surface of $\mathrm{BHI}$ agar with test microorganism

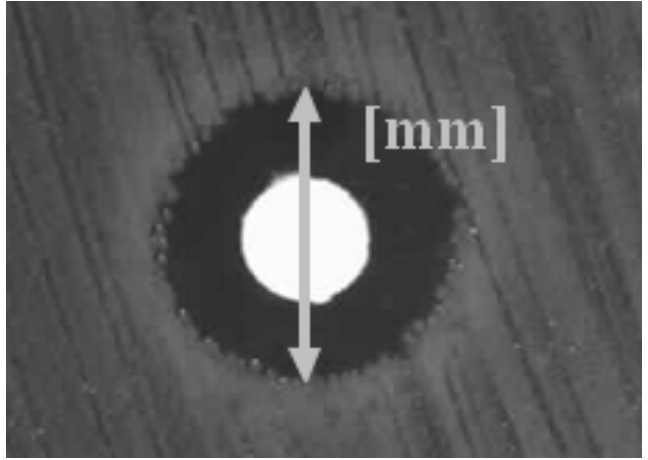

Fig. 2. Measurement of the inhibition zone diameter [mm]
Plates were then incubated at $37^{\circ} \mathrm{C}$ for 24 (S. aureus and E. coli) and 48 hours (C. albicans). After the incubation period, plates were removed from the incubator and the diameter of growth inhibition zones was measured using a ruler (Fig. 2).

The test was performed in triplicate for $S$. aureus and $E$. coli strains and in duplicate for the $C$. albicans strain in order to average the later results. 
To determine and characterize the inhibition zones diameter of test microorganisms, the test was proceeded in accordance to data provided in the study by Rusenova and Parvanov (2009). Individual diameters of inhibition zones along with determination of the extent of TSL antimicrobial activity allowing for the correct interpretation of the results are provided in Table 1.

Table 1. Diameters of inhibition zones and the antimicrobial activity range of TSL

\begin{tabular}{cc}
\hline $\begin{array}{c}\text { Inhibition zone diameter } \\
{[\mathrm{mm}]}\end{array}$ & Antimicrobial activity \\
\hline$\geq 20$ & big - strong inhibitory effect \\
\hline $20-12$ & moderate - weak inhibitory effect \\
\hline$<12$ & small - no inhibitory effect \\
\hline
\end{tabular}

The obtained data were analysed by Kruskal-Wallis ANOVA. $P$ values lower than 0.05 were considered statistically significant. All statistical analysis was carried out using OriginPro 8.1 (OriginLab Corporation).

\section{RESULTS}

Tested EO showed different antimicrobial activity against used microorganisms (Fig. 3 and Table 2, 3 and 4). Based on the reference values (Table 1), it was found that TSL showed only moderate antimicrobial activity against both $S$. aureus and $E$. coli at concentrations of 200 and $125 \mu \mathrm{L} / \mathrm{mL}$ and no effect at lower concentrations. In turn, high inhibitory activity was observed against $C$. albicans at concentrations of 200,125 and $62.5 \mu \mathrm{L} / \mathrm{mL}$, moderate at $31.2 \mu \mathrm{L} / \mathrm{mL}$ and no effect at lower concentrations. At the same time, it was confirmed that one of the main components of TSL - carvacrol, showed strong inhibitory effect on all tested microorganisms (Table 2, 3 and 4). Obtained results also showed, that there is a statistically significant difference between used TSL concentration and inhibition zone diameters of the tested microorganism.

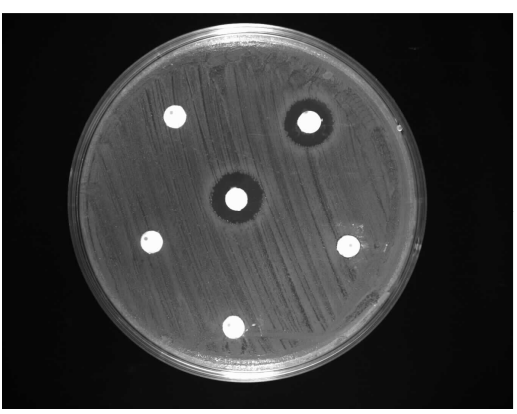

Escherichia coli

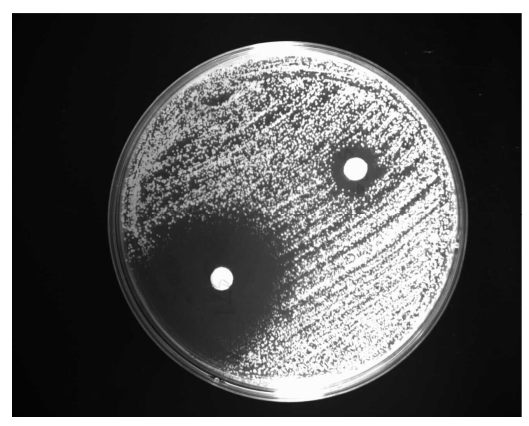

Candida albicans

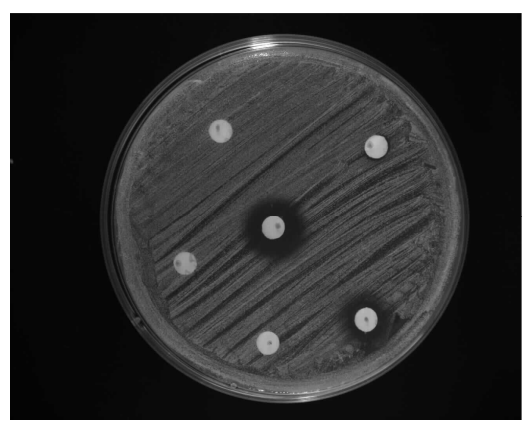

Staphylococcus aureus

Fig. 3. Exemplary zones of inhibition induced by TSL activity against test microorganisms observed in the disk diffusion assay 
Table 2. List of diameters of $S$. aureus growth inhibition zones and TSL concentration (including carvacrol)

\begin{tabular}{cccc}
\hline & \multicolumn{2}{c}{ Staphylococcus aureus } & \\
\hline $\begin{array}{c}\text { concetration } \\
{[\mu \mathrm{L} / \mathrm{mL}]}\end{array}$ & $\begin{array}{c}\text { measurement } \\
\text { No. } 1[\mathrm{~mm}]\end{array}$ & $\begin{array}{c}\text { measurement } \\
\text { No. 2 }[\mathrm{mm}]\end{array}$ & $\begin{array}{c}\text { measurement } \\
\text { No. 3 }[\mathrm{mm}]\end{array}$ \\
\hline 200 & 12 & 12 & 12 \\
\hline 125 & 10 & 11 & 15 \\
\hline 62.5 & 10 & 7.5 & 12 \\
\hline 31.2 & 8 & 6.5 & 7 \\
\hline 15.6 & 5.5 & 5.5 & 0 \\
\hline 7.8 & 0 & 0 & 0 \\
\hline 3.9 & 0 & 0 & 0 \\
\hline 2.0 & 0 & 0 & 0 \\
\hline 0 & 0 & 0 & $>20$ \\
\hline Carvacrol 100\% & $>20$ & $>20$ & \\
\hline
\end{tabular}

Table 3. List of diameters of $E$. coli growth inhibition zones and TSL concentration (including carvacrol)

\begin{tabular}{cccc}
\hline & \multicolumn{2}{c}{ Escherichia coli } & \\
\hline $\begin{array}{c}\text { concetration } \\
{[\mu \mathrm{L} / \mathrm{mL}]}\end{array}$ & $\begin{array}{c}\text { measurement } \\
\text { No. } 1[\mathrm{~mm}]\end{array}$ & $\begin{array}{c}\text { measurement } \\
\text { No. 2 }[\mathrm{mm}]\end{array}$ & $\begin{array}{c}\text { measurement } \\
\text { No. 3 }[\mathrm{mm}]\end{array}$ \\
\hline 200 & 14 & 14 & 14 \\
\hline 125 & 9 & 11 & 20 \\
\hline 62.5 & 9 & 10.5 & 12 \\
\hline 31.2 & 8 & 7 & 10 \\
\hline 15.6 & 6.5 & 6 & 8 \\
\hline 7.8 & 0 & 0 & 0 \\
\hline 3.9 & 0 & 0 & 0 \\
\hline 2.0 & 0 & 0 & 0 \\
\hline 0 & 0 & 0 & $>20$ \\
\hline
\end{tabular}

Table 4. List of diameters of $C$. albicans growth inhibition zones and TSL concentration (including carvacrol)

\begin{tabular}{ccc}
\hline & Candida albicans & \\
\hline $\begin{array}{c}\text { concetration } \\
{[\mu \mathrm{L} / \mathrm{mL}]}\end{array}$ & $\begin{array}{c}\text { measurement } \\
\text { No. 1 }[\mathrm{mm}]\end{array}$ & $\begin{array}{c}\text { measurement } \\
\text { No. 2 }[\mathrm{mm}]\end{array}$ \\
\hline 200 & $>20$ & $>20$ \\
\hline 125 & 44 & 36 \\
\hline 62.5 & 32 & 25 \\
\hline 31.2 & 26 & 11 \\
\hline 15.6 & 8 & 7 \\
\hline 7.8 & 0 & 0 \\
\hline 3.9 & 0 & 0 \\
\hline 2.0 & 0 & 0 \\
\hline 0 & 0 & $>20$ \\
\hline Carvacrol $100 \%$ & $>20$ & 0 \\
\hline
\end{tabular}

Considering the averaged values of diameters of inhibited growth zones of test microorganisms against individual concentrations of the essential oil TSL, the so-called MIC (minimal inhibitory concentration), or values corresponding to the minimum inhibitory concentration expressed in $\mu \mathrm{L} / \mathrm{mL}$, were assesed (Fig. 4, 5 and 6). MIC values were shown as light grey bars in the graphs. 


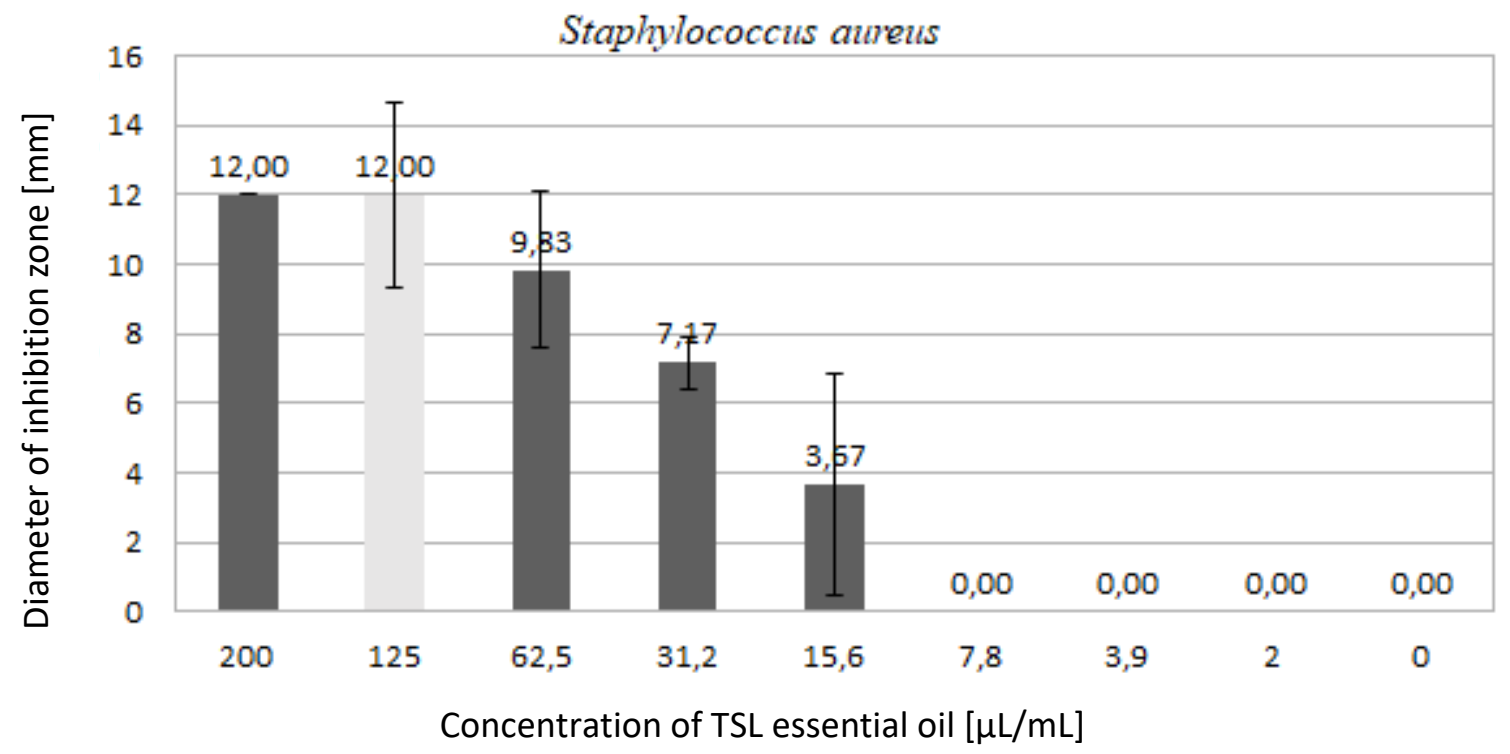

Fig. 4. Relationship between the concentration of the essential oil TSL and the averaged zone of inhibition of $S$. aureus with the marked MIC value

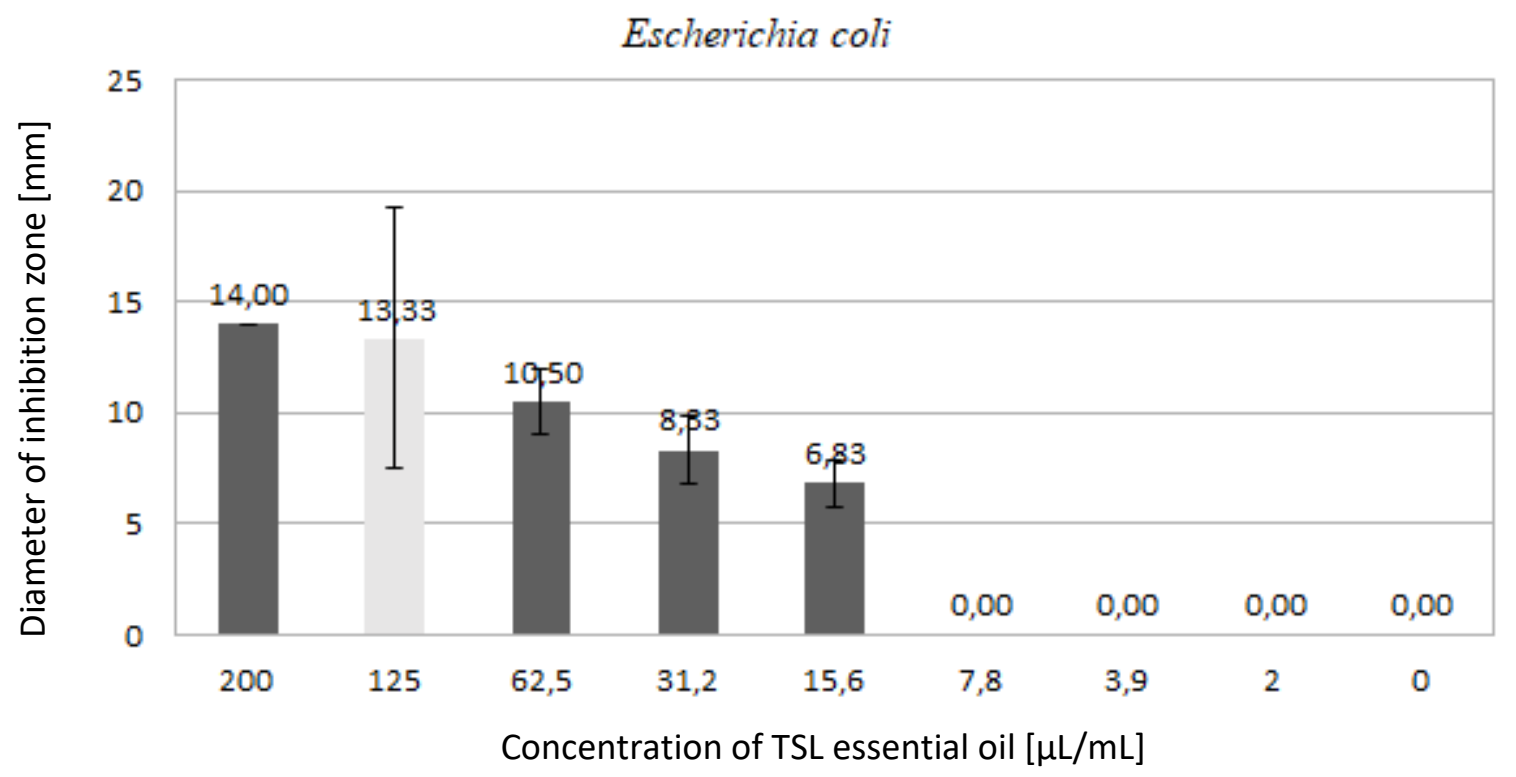

Fig. 5. Relationship between the concentration of the essential oil TSL and the averaged zone of inhibition of $E$. coli with the marked MIC value 


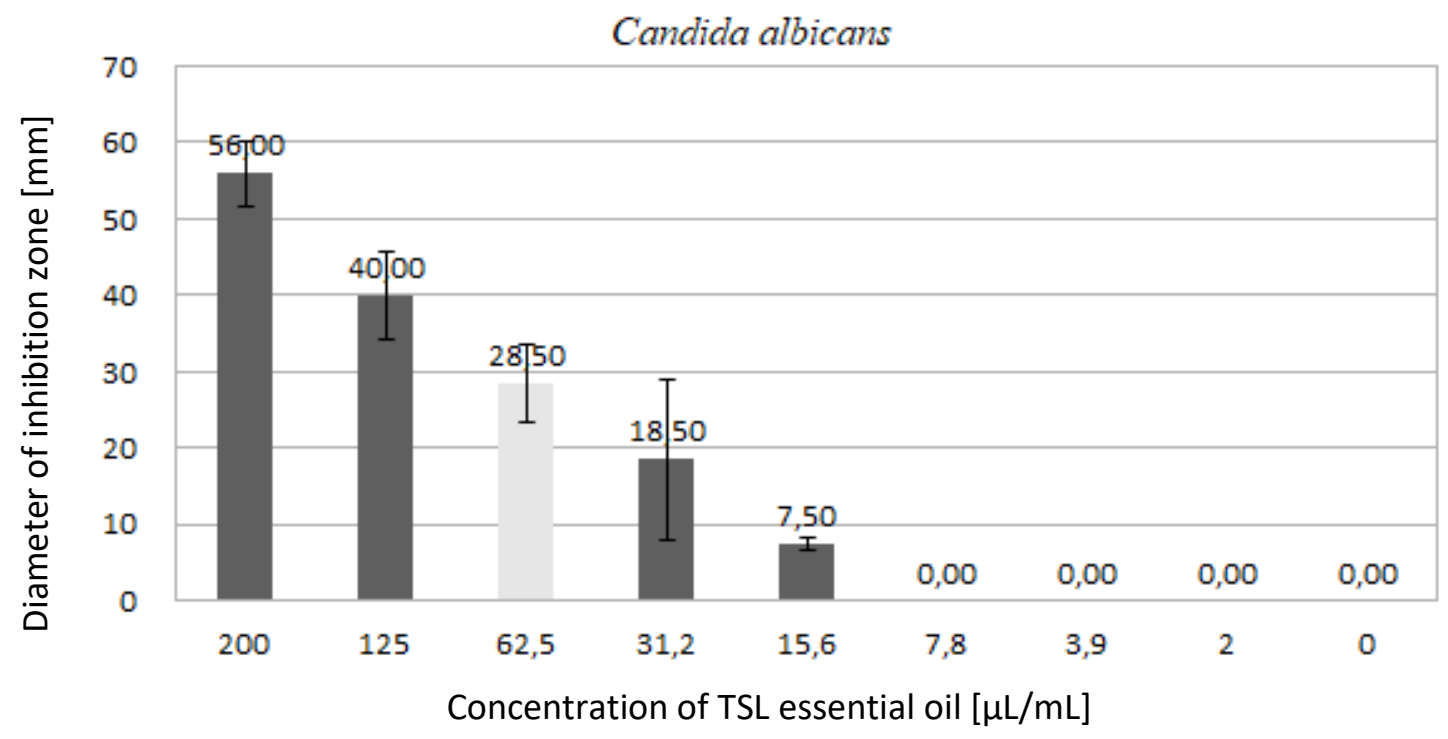

Fig. 6. Relationship between the concentration of the essential oil TSL and the averaged zone of inhibition of $C$. albicans with the marked MIC value

The MIC value determined for the $C$. albicans being $62.5 \mu \mathrm{L} / \mathrm{mL}$ was considered the most effective for the tested TSL essential oil, because it is the lowest concentration of this substance, at which there is a strong inhibitory effect. This dependence is illustrated in Fig. 7, where the MIC values $[\mu \mathrm{L} / \mathrm{mL}]$ determined for individual microorganisms are compared to the corresponding averaged values of diameters of inhibited growth zones [mm]. The MIC of the TSL essential oil for $C$. albicans was the lowest with the largest zone of inhibited growth. In turn, the MIC of the TSL essential oil for E. coli and $S$. aureus had the same value, while diameters of inhibited growth were much smaller and differed slightly between themselves.

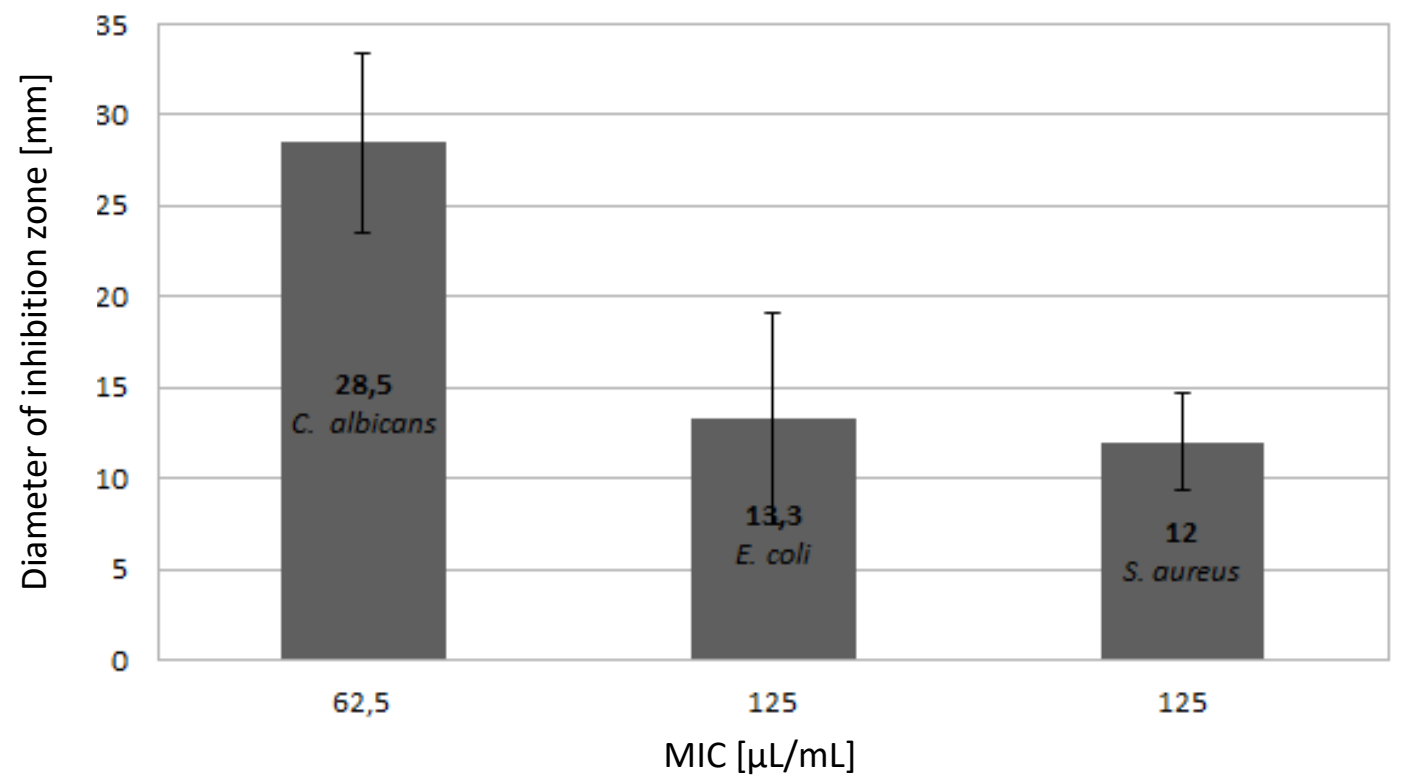

Fig. 7. Comparison of MIC values for the investigated microorganisms against corresponding averaged values of inhibited growth zones 


\section{DISCUSSION}

There are many well-known EOs that have proven bactericidal and fungicidal properties. In the era of widespread interest in the topic of ineffectiveness of antibiotic therapy and antibiotic resistance of microorganisms, EOs can naturally replace some antibiotics or become their synergistic supplement (Kwiatkowski et al. 2018). Espiecially hope bringing are the results from studies, in which sensitivity of penicillin-sensitive and penicillin-resistant Streptococcus pneumoniae strains to EOs has been demonstrated (Inouye et al. 2001). Apart from the effective activity, EOs as bioactive substances, are also characterized by the ease of their acquiring from natural environment. In addition, many techniques for oil extracting are not complicated processes. For this reason, the constant search for new essential oils and the study upon their properties seem fully justified.

An interesting example and object of research can be the essential oil obtained from wild thyme (Thymus serpyllum), because there is relatively little data on this EO. In our study, three test microorganisms were used to assess the antimicrobial activity of TSL, representing three characteristic groups: Gram-negative rods (Escherichia coli), Gram-positive cocci (Staphylococcus aureus) and yeast (Candida albicans). This choice allowed a broad look onto the activity of the TSL oil and defining its scope of action for future use. Tested EO showed variable effect on the test microorganisms, depending on the strain and TSL concentration. Comparing the mean values of diameters of inhibited growth zones (Table 2, 3 and 4), it was found that TSL oil was particularly active against the C. albicans strain, exerting a strong inhibitory effect on its growth. This allowed to determine the effective MIC value and to classify the analyzed EO oil into a substance with mainly fungicidal activity. It can also be concluded that TSL oil shows slightly higher bactericidal activity against Gram-negative than Gram-positive microorganisms.

In other studies on the EO obtained from Thymus serpyllum, it was found that it had minimal inhibitory activity already at the concentration of approx. $1.56 \mu \mathrm{L} / \mathrm{mL}$ against $E$. coli and $3.125 \mu \mathrm{L} / \mathrm{mL}$ against $S$. aureus (Lević et al. 2011), as well as at concentrations of $2.5-5 \mu \mathrm{g} / \mathrm{mL}$ and $1-2 \mu \mathrm{g} / \mathrm{mL}$ against all tested microorganisms, proving to be the most effective oil among the tested ones and with the best antioxidant activity. It was also shown that TSL oil did not show any toxic effects on pig liver cell cultures at any of the tested concentrations (> $400 \mu \mathrm{g} / \mathrm{mL}$ ) (Nikolić et al. 2014). In turn, in the studies of Pióro-Jabrucka et al. (2007), the oil showed MIC at 2000-3000 $\mu \mathrm{L} / \mathrm{mL}$ against $S$. aureus and $>8500 \mu \mathrm{L} / \mathrm{mL}$ against $E$. coli depending on the population of wild thyme. Such a large discrepancy of results may be caused by the amount and concentration of active ingredients in the oil, different scheme of the research methodology or the conditions for growing the wild thyme. It should also be noted that in the studies cited, the influence of oil on fungi was not analyzed.

A big threat in the context of human and livestock health are undoubtedly fungal toxins and in particular aflatoxins produced by fungi of the genus Aspergillus, which were officially recognized in Poland in 1996 as carcinogenic substances. Studies show that essential oils of the Lamiaceae family inhibit the growth of Aspergillus fungi, and thus the secretion of aflatoxins (Gorran et al. 2013). They also inhibit the development of fungal flora and the production of mycotoxins by fungi of the genus Fusarium on contaminated wheat seeds, which is a common ingredient of fodders (Sumalan et al. 2013). 
It is worth mentioning that these positive properties of the oil are conditioned by its active substances - phenols. One of them is carvacrol, that in the studies of Kim et al. (1995) showed a very strong bactericidal activity against five pathogenic microorganisms derived from food. Also, in our own studies, a strong inhibitory effect of carvacrol against three test microorganisms was confirmed. It also appears that the amount of phenols in plants from the Lamiaceae family can be regulated and increased by exposing them to the physical and chemical factors of positive stress (Trivellini et al. 2016). It can therefore be assumed that by exposing the wild thyme to positive stress factors, it will be possible to obtain an increased concentration of carvacrol in the oil, while maintaining its other properties, such as pleasant scent. Thus, it can be assumed that the TSL essential oil will be used as an ingredient in the washing and disinfecting agents without worrying about its toxicity.

\section{CONCLUSIONS}

A large variety of relatively simple and cheap methods of acquisition, and above all, numerous possibilities of using essential oils, including TSL oil, cause the increasing interest for these biologically active substances of natural origin. Beacause of the emerging problem of the increase in antibiotic resistance among bacteria, also of microbiome origin, there is a constant need to search, obtain and evaluate antimicrobial activity of useful, biologically active substances. In this study, we showed that TSL essential oil has a strong antifungal activity as well as its main component - carvacrol, which can act both as fungicidal and bactericidal agent. Because of these properties, they may be used in prophylaxis and therapy of fungal infections, possibly in the animal industry, or be an alternative to chemical crops protection products.

\section{REFERENCES}

Borowska D., Jablonski A., Pejsak Z. 2014. Metoda krążkowo-dyfuzyjna w weterynaryjnej diagnostyce bakteriologicznej - praktyczne dane [The disk-diffusion method in the veterinary bacteriological diagnosis - practical data]. Życie Weter. 89(02), 116-120. [in Polish]

Buczek K., Marć M. 2009. Bacterial antibiotic resistance-reasons and effects. Ann. UMCS. Med. Veter. 64(3), 1-8.

Burt S. 2004. Essential oils: their antibacterial properties and potential applications in foods a review. International J. Food Microbiol. 94(3), 223-253.

Gorran A., Farzaneh M., Shivazad M., Rezaeian M., Ghassempour A. 2013. Aflatoxin B1-reduction of Aspergillus flavus by three medicinal plants (Lamiaceae). Food Control 31(1), 218-223.

Inouye S., Takizawa T., Yamaguchi H. 2001. Antibacterial activity of essential oils and their major constituents against respiratory tract pathogens by gaseous contact. J. Antimicrob. Chemother. 47(5), 565-573.

Kim J., Marshall M.R., Wei C.I. 1995. Antibacterial activity of some essential oil components against five foodborne pathogens. J. Agric. Food Chem. 43(11), 2839-2845.

Król S. K., Skalicka-Woźniak K., Kandefer-Szerszeń M., Stepulak A. 2013. Aktywność biologiczna i farmakologiczna olejków eterycznych w leczeniu i profilaktyce chorób infekcyjnych [Biological and pharmacological activity of essential oils in the treatment and prevention of infectious diseases]. Post. Hig. Med. Dośw. 67, 1000-1007, http://www.phmd.pl/fulltxt.php?ICID=1067687, access: 22.09.2013. [in Polish] 
Kwiatkowski P., Pruss A., Grygorcewicz B., Wojciuk B., Dołęgowska B., Giedrys-Kalemba S., Kochan E., Sienkiewicz M. 2018. Preliminary study on the antibacterial activity of essential oils alone and in combination with gentamicin against extended-spectrum $\beta$-lactamase-producing and New Delhi metallo- $\beta$-lactamase-1-producing Klebsiella pneumoniae isolates. Microb. Drug Res. 24(9), 1368-1375, http://doi.org/10.1089/mdr.2018.0051.

Lević J., Čabarkapa I., Todorović G., Pavkov S., Sredanivić S., Coghill-Galonja T., Kostadinović L. 2011. In vitro antibacterial activity of essential oils from plant family Lamiaceae. Romanian Biotechnol. Lett. 16(2), 6034-6041.

Kebkowska M. 2009. Występowanie bakterii antybiotykoopornych w wodzie przeznaczonej do spożycia przez ludzi [The occurrence of antibiotic-resistant bacteria in water intended for human consumption]. Ochr. Środ. 31(2), 11-15. [in Polish]

Nikolić M., Glamočlija J., Ferreira I.C., Calhelha R.C., Fernandes Â., Marković T., Marković D., Giweli A., Soković M. 2014. Chemical composition, antimicrobial, antioxidant and antitumor activity of Thymus serpyllum L., Thymus algeriensis Boiss. and Reut and Thymus vulgaris L. essential oils. Ind. Crops Prod. 52, 183-190.

Orzeszko-Rywka A., Rochalska M., Chamczyńska M. 2010. Ocena przydatności olejków roślinnych do zaprawiania nasion wybranych roślin uprawnych [Evaluation of the usefulness of vegetable oils for seed treatment of selected crop plants]. J. Res. Appl. Agric. Eng. 55(4), 36-41. [in Polish]

Ożarowski A., Jaroniewski W. 1987. Rośliny lecznicze i ich praktyczne zastosowanie. Warszawa, Instyt. Wydaw. Zw. Zawod., 239-240. [in Polish]

Pióro-Jabrucka E., Suchorska-Tropilo K., Rzewuska M. 2007. Antibacterial activity of the essential oil of common thyme (Thymus pulegioides L.) and wild thyme (Thymus serpyllum L.). Herba Pol. 3(53), 297-301.

Rusenova N., Parvanov P. 2009. Antimicrobial activities of twelve essential oils against microorganisms of veterinary importance. Trakia J. Sci. 7(1), 37-43.

Skandamis P., Koutsoumanis K., Fasseas K., Nychas G.E. 2001. Inhibition of oregano essential oil and EDTA on Escherichia coli O157: H7. Italian J. Food Sci. 13(1), 65-75.

Stammati A., Bonsi P., Zucco F., Moezelaar R., Alakomi H.L., Von Wright A. 1999. Toxicity of selected plant volatiles in microbial and mammalian short-term assays. Food Chem. Toxicol. 37(8), 813-823.

Sumalan R.M., Alexa E., Poiana M.A. 2013. Assessment of inhibitory potential of essential oils on natural mycoflora and Fusarium mycotoxins production in wheat. Chem. Centr. J. 7(1), 1-12.

Trąba C., Rogut K., Wolański P. 2012. Rośliny dziko występujące i ich zastosowanie. Przewodnik po wybranych gatunkach. Rzeszów, Stowarzyszenie na rzecz Rozwoju i Promocji Podkarpacia Pro Carpathia, 94. [in Polish]

Trivellini A., Lucchesini M., Maggini R., Mosadegh H., Villamarin T.S.S., Vernieri P., Mensuali-Sodi A., Pardossi A. 2016. Lamiaceae phenols as multifaceted compounds: bioactivity, industrial prospects and role of "positive-stress". Ind. Crops Prod. 83, 241-254.

Wesołowska A., Grzeszczuk M., Jadczak D., Nawrotek P., Struk M. 2015. Comparison of the chemical composition and antimicrobial activity of Thymus serpyllum essential oils. Notulae Bot. Hort. Agrobot. Cluj-Napoca 43(2), 432-438.

Wesołowska A., Grzeszczuk M., Jadczak D. 2014. Comparison of chemical compositions of essential oils isolated by hydrodistillation from wild thyme (Thymus serpyllum L.) with use of Deryng and Clevenger apparatus. Herba Pol. 60(2), 7-17.

Wesołowska A., Jadczak D., Grzeszczuk M. 2012. Influence of distillation time on the content and composition of essential oil isolated from wild thyme (Thymus serpyllum L.). Herba Pol. 58(4), 40-50. 


\title{
AKTYWNOŚĆ PRZECIWBAKTERYJNA I PRZECIWGRZYBICZA OLEJKU ETERYCZNEGO Z MACIERZANKI PIASKOWEJ (Thymus serpyllum)
}

\begin{abstract}
Streszczenie. Celem pracy było wykazanie in vitro aktywności antymikrobiologicznej olejku eterycznego pozyskanego z macierzanki piaskowej (Thymus serpyllum) wobec trzech mikroorganizmów testowych reprezentujących gatunki: Escherichia coli, Staphylococcus aureus i Candida albicans. Badania przeprowadzone zostały z użyciem metody dyfuzyjno-krążkowej. Aktywność olejku TSL analizowano w różnym zakresie stężeń - od $200 \mu \mathrm{L} / \mathrm{mL}$ do 2,0 $\mu \mathrm{L} / \mathrm{mL}$, poddając ocenie wielkość stref zahamowanego wzrostu. Po uśrednieniu uzyskanych wartości określano zakres aktywności antymikrobiologicznej TSL na podstawie danych referencyjnych. Olejek eteryczny TSL wykazywał jedynie umiarkowane działanie hamujące wobec S. aureus i E. coli w stężeniu 200 i $125 \mu \mathrm{L} / \mathrm{mL}$ oraz duże działanie inhibujące wobec C. albicans w stężeniu 200, 125 i 62,5 $\mu \mathrm{L} / \mathrm{mL}$ i umiarkowane w stężeniu $31,2 \mu \mathrm{L} / \mathrm{mL}$. Na tej podstawie wyznaczono wartość MIC dla szczepu testowego C. albicans wynoszącą $62,5 \mu \mathrm{L} / \mathrm{mL}$, uznając ją za najbardziej efektywną w przypadku badanego olejku eterycznego TSL. Ponadto ustalono, że karwakrol - jeden z głównych składników TSL - może wykazywać silne działanie hamujące wzrost zarówno w przypadku wybranych gatunków grzybów, jak i bakterii.
\end{abstract}

Słowa kluczowe: aktywność antymikrobiologiczna, olejek eteryczny, macierzanka piaskowa, Thymus serpyllum. 